\title{
Rainfall thresholds for shallow landslide occurrence in Calabria, southern Italy
}

\author{
C. Vennari ${ }^{1}$, S. L. Gariano ${ }^{2}$, L. Antronico ${ }^{2}$, M. T. Brunetti ${ }^{3,4}$, G. Iovine $^{2}$, S. Peruccacci ${ }^{3}$, O. Terranova ${ }^{2}$, and \\ F. Guzzetti ${ }^{3}$ \\ ${ }^{1}$ CNR IRPI, via Amendola 122 I, 70126 Bari, Italy \\ ${ }^{2}$ CNR IRPI, via Cavour 6, 87036 Rende (CS), Italy \\ ${ }^{3}$ CNR IRPI, via Madonna Alta 126, 06128 Perugia, Italy \\ ${ }^{4}$ Università degli Studi di Perugia, Dipartimento di Scienze della Terra, Piazza Università, 06123 Perugia, Italy
}

Correspondence to: S. L. Gariano (gariano@irpi.cnr.it)

Received: 22 August 2013 - Published in Nat. Hazards Earth Syst. Sci. Discuss.: 27 September 2013

Revised: 2 January 2014 - Accepted: 17 January 2014 - Published: 20 February 2014

\begin{abstract}
In many areas, rainfall is the primary trigger of landslides. Determining the rainfall conditions responsible for landslide occurrence is important, and may contribute to saving lives and properties. In a long-term national project for the definition of rainfall thresholds for possible landslide occurrence in Italy, we compiled a catalogue of 186 rainfall events that resulted in 251 shallow landslides in Calabria, southern Italy, from January 1996 to September 2011. Landslides were located geographically using Google Earth ${ }^{\circledR}$, and were given a mapping and a temporal accuracy. We used the landslide information, and sub-hourly rainfall measurements obtained from two complementary networks of rain gauges, to determine cumulated event vs. rainfall duration $(E D)$ thresholds for Calabria. For this purpose, we adopted an existing method used to prepare rainfall thresholds and to estimate their associated uncertainties in central Italy. The regional thresholds for Calabria were found to be nearly identical to previous $E D$ thresholds for Calabria obtained using a reduced set of landslide information, and slightly higher than the $E D$ thresholds obtained for central Italy. We segmented the regional catalogue of rainfall events with landslides in Calabria into lithology, soil regions, rainfall zones, and seasonal periods. The number of events in each subdivision was insufficient to determine reliable thresholds, but allowed for preliminary conclusions about the role of the environmental factors in the rainfall conditions responsible for shallow landslides in Calabria. We further segmented the regional catalogue based on administrative subdivisions used for hydro-meteorological monitoring and operational flood
\end{abstract}

forecasting, and we determined separate $E D$ thresholds for the Tyrrhenian and the Ionian coasts of Calabria. We expect the $E D$ rainfall thresholds for Calabria to be used in regional and national landslide warning systems. The thresholds can also be used for landslide hazard and risk assessments, and for erosion and landscape evolution studies, in the study area and in similar physiographic regions in the Mediterranean area.

\section{Introduction}

In Italy, rainfall-induced landslides are common geomorphological events that cause economic and environmental damage, and casualties (Salvati et al., 2010). Due to the morphological, geologic and climatic settings, rainfall-induced landslides are frequent and abundant in Calabria, a region in southern Italy (Sorriso-Valvo, 1993; Gullà et al., 2008; Iovine et al., 2009; Trigila et al., 2010). In the framework of a national project for the definition of rainfall thresholds for possible landslide occurrence, and for the implementation of a nationwide landslide warning system in Italy (Brunetti et al., 2010; Rossi et al., 2012), we have defined empirical rainfall thresholds for shallow landslide occurrence in Calabria.

In this work, we introduce the landslide information and the rainfall data used to define the thresholds in Calabria, we present the regional thresholds and their uncertainties, and we discuss limits to the definition of rainfall thresholds for possible landslide occurrence in the region. The 
paper is organized as follows. In Sect. 2, we provide background information on the definition and use of empirical rainfall thresholds for landslide occurrence, focusing on cumulated event rainfall - rainfall duration $(E D)$ thresholds (Guzzetti et al., 2007, 2008). This is followed by a description of the study area (Sect. 3), and of the data used and the method adopted to define the thresholds (Sect. 4). In Sect. 5, we present the $E D$ thresholds, including regional thresholds, and thresholds prepared for different subdivisions based on lithology, soil types, rainfall and seasonal characteristics, and administrative subdivisions for hydro-meteorological monitoring and forecasting. Next, we discuss the results obtained and we compare the $E D$ thresholds defined for Calabria to similar thresholds available for other areas in Italy. We conclude (Sect. 7), summarizing the lessons learned.

\section{Background}

In the literature, rainfall-induced shallow landslides, including soil slips, soil slides, debris flows, and rock falls (Cruden and Varnes, 1996), are predicted using empirical rainfall thresholds or spatially distributed, physically based numerical models. In this work, we concentrate on the definition of rainfall thresholds for the possible occurrence of shallow landslides. Most commonly, a threshold defines the lower bound of known rainfall conditions that resulted in landslides (e.g. Reichenbach et al., 1998; Corominas, 2000; Crosta and Frattini, 2001; Aleotti, 2004; Wieczorek and Glade, 2005). To establish a threshold, different types of rainfall measurements can be used (Guzzetti et al., 2007). Inspection of the literature reveals that most of the thresholds are determined considering the duration $(D$, in $\mathrm{h})$ of the rainfall events, the event cumulated rainfall $(E$, in $\mathrm{mm})$ or the mean rainfall intensity $\left(I\right.$, in $\left.\mathrm{mm} \mathrm{h}^{-1}\right)$ of the events that resulted in landslides. Rainfall thresholds can be defined for different geographical areas, from local to global thresholds (Guzzetti et al., 2007, 2008).

Endo (1969), working on Hokkaido, Japan, was probably the first to introduce the concept of a minimum amount of rainfall necessary to trigger a landslide. Onodera et al. (1974), also working in Japan, were the first to propose quantitative rainfall thresholds for the possible initiation of landslides. Campbell (1975) studied the rainfall conditions that triggered soil slips in southern California in 1969, and suggested that the failures were the result of the combination of cumulated rainfall and event rainfall intensity. Caine (1980) collected information on 73 rainfall intensity $I$ vs. rainfall duration $D$ conditions responsible for shallow landslides globally, and was the first to propose a global (minimum) $I D$ threshold expressed by the power-law equation $I=14.82$. $D^{-0.39}$. Based on this relationship, when $I<14.82 \cdot D^{-0.39}$ landslide activity is unlikely. Innes (1983) used information on 35 rainfall events that had resulted in debris flows worldwide to establish a global minimum cumulated rainfall event $E$ - rainfall duration $D(E D)$ threshold for possible debris flow occurrence, given by the power-law equation $E=4.9355 \cdot D^{0.5041}$. Again, based on this relationship, when $E<4.9355 \cdot D^{0.5041}$ debris flow activity is unlikely. More recently, Kanji et al. (2003) collected information on the rainfall conditions that resulted in debris flows and landslides in several geographical areas, and proposed the global minimum $E D$ threshold $E=22.4 \cdot D^{0.41}$.

Guzzetti et al. $(2007,2008)$ reviewed the literature on rainfall thresholds for possible landslide occurrence and recognized that many of the thresholds were defined using illformalized, poorly documented, or non-reproducible methods. The lack of standards has negative consequences for the possible use of the thresholds. In an attempt to measure the uncertainty inherent in the thresholds, Brunetti et al. (2010) and Peruccacci et al. (2012) proposed an objective method for the definition of empirical rainfall thresholds based on a statistical frequentist approach. In particular, Brunetti et al. (2010) collected information on 753 rainfall events that triggered landslides in Italy from 1841 to 2009, and defined ID thresholds for Italy and for the Abruzzo region, central Italy. The regional $I D$ threshold for Abruzzo was found to be lower than the threshold defined for Italy, and lower than similar regional $I D$ thresholds defined for areas in northern Italy by Aleotti (2004) and Ceriani et al. (1994), and in southern Italy by Calcaterra et al. (2000). Peruccacci et al. (2012) compiled a new catalogue of 442 rainfall events that triggered landslides in the Abruzzo, Marche, and Umbria regions, central Italy, between 2002 and 2010, modified the method proposed by Brunetti et al. (2010) to consider the uncertainties associated with the definition of the parameters defining the thresholds, and proposed $E D$ thresholds for different exceedance probabilities for the entire study area and for three administrative subdivisions, for the main lithological domains, and for different seasonal periods. The cumulated rainfall necessary to trigger landslides in the study area was found to be slightly larger for flysch deposits than for soft post-orogenic sediments (clay, silt, sand, gravel) and for sedimentary carbonate rocks. The thresholds for the dry and the wet seasonal periods were found to be indistinguishable for rainfall durations in the range $12 \leq D \leq 100 \mathrm{~h}$.

\section{Study area}

Our study area comprises the Calabria region that extends for $15080 \mathrm{~km}^{2}$ in southern Italy with elevation in the range from sea level to $2267 \mathrm{~m}$ at Monte Serra Dolcedorme, in the Pollino range (Fig. 1). Most of the area consists of crystalline-metamorphic nappes, Palaeozoic in age, that form the Calabrian Arc, and that were thrust onto MesozoicCenozoic units comprising the Apennines mountain chain, and were then covered by sedimentary rocks, Miocene to Quaternary in age (Amodio Morelli et al., 1976). The Calabrian-Sicilian rift zone (Monaco and Tortorici, 2000), 


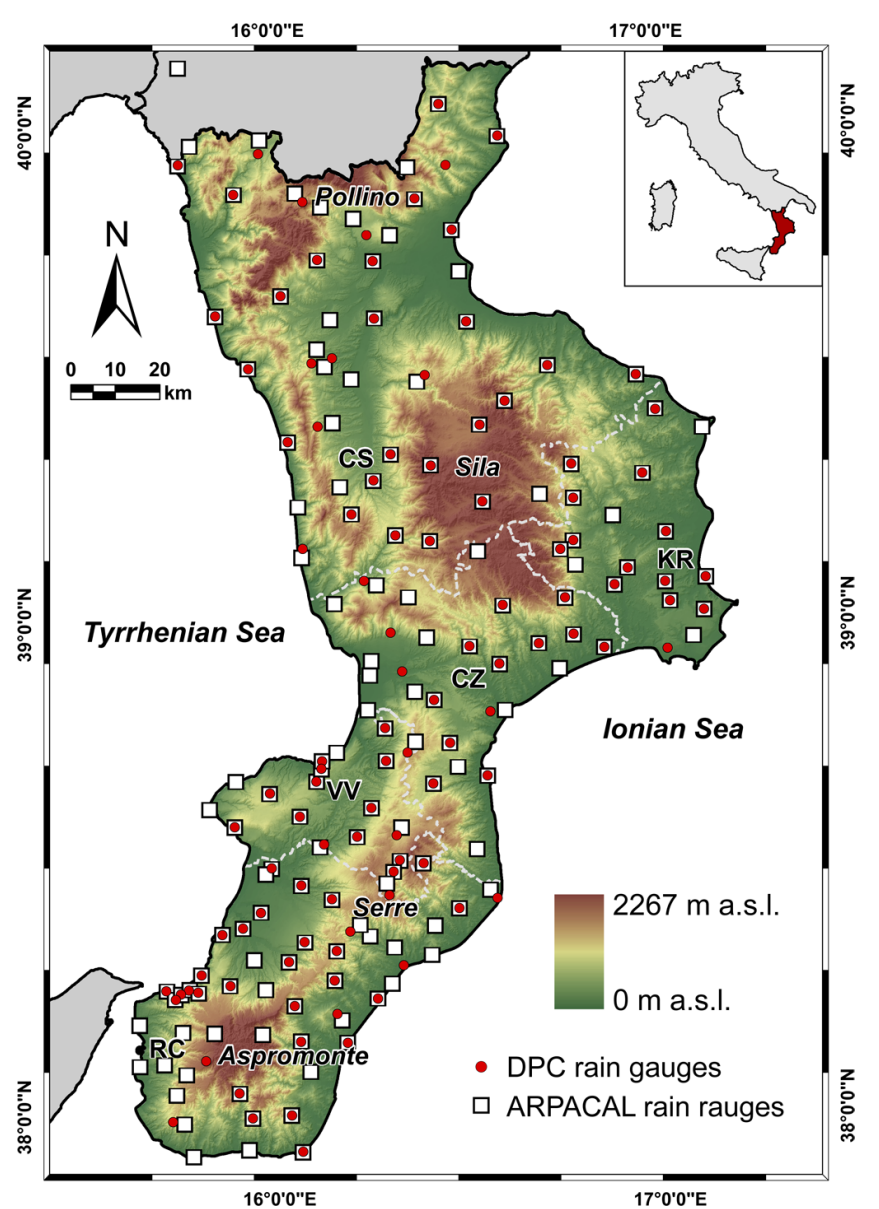

Fig. 1. Terrain elevation map for Calabria, southern Italy. Shades of colour show terrain elevations from sea level (dark green) to $2267 \mathrm{~m}$ (brown). Red dots show location of rain gauges of the National Department of Civil Protection. White squares show location of rain gauges of the Regional Agency for Environmental Protection in Calabria. White dashed lines are province boundaries. Legend: CS, Cosenza; CZ, Catanzaro; KR, Crotone; RC, Reggio di Calabria; VV, Vibo Valentia.

a system of active normal faults along the western side of the Calabrian Arc, produced intense regional uplift. The uplift started in the Pleistocene, and was responsible for the intense historical seismicity of the area (Monachesi and Stucchi, 1997; Boschi et al., 2000). Due to the complex geodynamic history (Monaco and Tortorici, 2000; Tortorici et al., 1995; Westaway, 1993), in Calabria rocks are highly deformed, fragmented, and deeply weathered. Landscape is hilly or mountainous, with lowlands confined to local tectonic depressions and along the coasts. The mountains are made of crystalline-metamorphic rocks mantled by thick soils, except in the northernmost portion of the region and in tectonic windows where carbonate rocks crop out. In the hills crop out clastic sediments, whereas clay, silt and sand are most abundant in the coastal plains. Orography controls the precipitation regime (Bellecci et al., 2002), which is driven by regional meteorological fronts approaching transversally the region, and by convective cells forming along the steep coastal slopes. Cumulated annual precipitation ranges from less than $500 \mathrm{~mm}$ along the coasts to more than $2000 \mathrm{~mm}$ in the mountains. About $70 \%$ to $80 \%$ of the annual precipitation falls from October to March, with only $10 \%$ of the precipitation in the summer. Intense summer storms are more frequent along the Ionian (eastern) coast than along the Tyrrhenian (western) coast (Terranova and Iaquinta, 2011). Due to the local setting, landslides of different types and sizes are abundant and frequent in Calabria (Sorriso-Valvo, 1993; Iovine et al., 2009). Recent regional studies have shown that approximately $23 \%$ of the territory is highly susceptible to shallow landslides (Gullà et al., 2008).

\section{Method}

To determine rainfall thresholds for possible shallow landslide occurrence in Calabria, we first prepared a catalogue of rainfall events that resulted in shallow landslides in the region in the 16-year period from January 1996 to September 2011. The catalogue was compiled searching national and local newspapers and journals, local historical archives, Internet blogs, and the scientific and technical literature. Additional information was obtained searching the archive of the local fire brigades of Cosenza Province. For each landslide we collected information on: (i) the geographical location of the landslide, including latitude, longitude and elevation, (ii) the time or period of occurrence of the slope failure, and (iii) the landslide type, classified according to Cruden and Varnes (1996). The geographical coordinates and the elevation of the individual landslides were obtained using Google Earth ${ }^{\circledR}$. Individual landslides were mapped as points, and were given a level of geographic accuracy, $P_{1}, P_{10}$, or $P_{100}$, depending on the detail of the information source. Adopting the approach proposed by Peruccacci et al. (2012), we considered a circular buffer to define high $\left(P_{1}<1 \mathrm{~km}^{2}\right)$, medium $\left(1 \leq P_{10}<10 \mathrm{~km}^{2}\right)$, or low $\left(10 \leq P_{100}<100 \mathrm{~km}^{2}\right)$ accuracy. Since accurate information on the time (or the period) of occurrence of a landslide is difficult to obtain and the temporal information is often affected by considerable uncertainty (Guzzetti et al., 2007), a level of temporal accuracy was assigned to each landslide, in three classes: high when the hour of occurrence of the failure was known, intermediate when the period of the day (e.g. morning, midday, afternoon, evening, night) was known, and low when only the day of occurrence was known.

When the geographical location and the time (or period) of occurrence of a landslide were established, the rainfall duration $D$ and the cumulated event rainfall $E$ that (presumably) caused the failure were determined using two synergic sources of rainfall information. The first source of information was the national database of rainfall measurements assembled and managed by the National Department 
for Civil Protection. For Calabria, and at the time of the study, this database contained sub-hourly rainfall measurements obtained by a network of 113 rain gauges. A second source of rainfall information was the regional database of sub-hourly rainfall measurements assembled and managed by the Calabria Regional Agency for Environmental Protection (ARPACAL). At the time of the study, this database contained rainfall measurements obtained by a network of 154 rain gauges. Figure 1 shows the geographical location and the spatial density of the rain gauges, and reveals that 75 rain gauges belong to both networks.

To determine the rainfall conditions considered responsible for a landslide, a "representative" rain gauge was selected. Selection of the rain gauge was decided according to the following general criteria: (i) the geographical distance between the landslide and the rain gauge should not exceed $12 \mathrm{~km}$, (ii) the elevation of the rain gauge and of the landslide should be comparable, and (iii) the general physiographical settings for the rain gauge and the landslide should also be comparable, e.g. they should be located on slopes facing the same direction, or in the same or in similar valleys.

When the representative rain gauge was selected, the rainfall conditions considered responsible for the landslide were computed. To determine the rainfall measurements, the most critical step was the selection of the "start time" and the "end time" of the rainfall event. For this purpose, the following criteria were adopted. The "end time" of the rainfall event was taken to coincide with the known or inferred time of the landslide occurrence (i.e. the hour, the end of the period of the day, or the end of the day for landslides characterized by a high, medium or low temporal accuracy, respectively). The "start time" of the rainfall event was decided based on a heuristic procedure that considered the (known or presumed) meteorological conditions resulting in the rainfall event. For events produced by regional frontal systems, a dry (no rain) period of two days between April and October (A-O), and of four days between November and March $(\mathrm{N}-\mathrm{M})$ was used to separate successive events. The difference between the two periods is justified by the Mediterranean climate that dominates the study area. For rainfall events produced by local convective conditions, the "start time" for the event was decided by searching visually for an abrupt (distinct) increase in the slope of the cumulated rainfall curve. This is similar to what was proposed by Aleotti (2004). When the "start time" and the "end time" of the rainfall event were decided, the rainfall duration $D$ (in hours) and the corresponding cumulated event rainfall $E$ (in $\mathrm{mm}$ ) were computed.

To determine the $E D$ rainfall thresholds, we adopted the method proposed by Brunetti et al. (2010), and improved by Peruccacci et al. (2012). The method allows for the definition of empirical rainfall thresholds for different exceedance probability levels, and for estimation of the uncertainty associated with the thresholds. This is a significant advantage over pre-existing, heuristic or subjective methods for the definition of rainfall thresholds (Guzzetti et al., 2007, 2008).

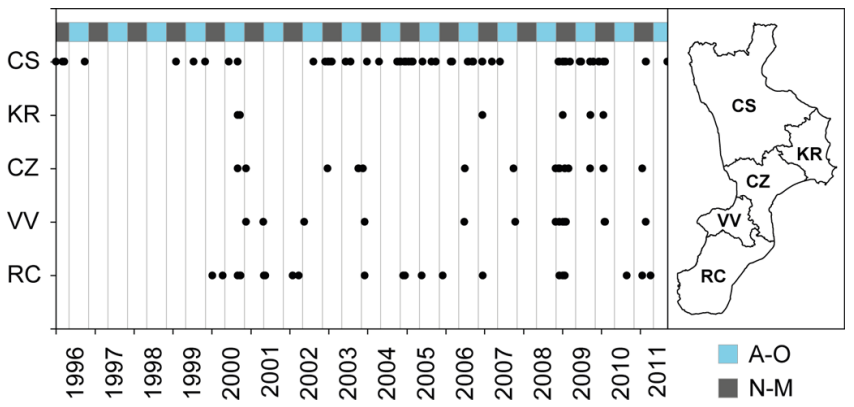

Fig. 2. Time distribution of 186 rainfall events that resulted in 251 landslides in the 16-year period from January 1996 to September 2011 in the five provinces of Calabria. Legend: A-O = April to October seasonal period, $\mathrm{N}-\mathrm{M}=$ November to March seasonal period. CS, Cosenza; CZ, Catanzaro; KR, Crotone; RC, Reggio di Calabria; VV, Vibo Valentia.

For the method, the threshold curves are described by power laws of the general form $E=(\alpha \pm \Delta \alpha) \cdot D^{(\gamma \pm \Delta \gamma)}$, where $\alpha$ is the scaling parameter (the intercept), $\gamma$ is the shape parameter (the exponent) that controls the slope of the power-law curve, and $\Delta \alpha$ and $\Delta \gamma$ are the uncertainties associated with $\alpha$ and $\gamma$, respectively. The method adopts a "bootstrap" nonparametric statistical technique (Efron, 1979; Efron and Tibshirani, 1994) to estimate the mean values of $\alpha$ and $\gamma$, and the associated uncertainties $\Delta \alpha$ and $\Delta \gamma$ (Peruccacci et al., 2012).

\section{Results}

Our final catalogue lists 186 rainfall events that resulted in 251 shallow landslides in Calabria in the period from January 1996 to September 2011. Table 1 and Fig. 2 summarize the abundance and the temporal distribution of the 186 triggering events in the five provinces in Calabria. The number of events is largest for Cosenza Province, which covers $44.1 \%$ of the region and comprises $60.2 \%$ of the listed events. The temporal distribution of the events is similar for the five provinces. In the catalogue, the number of rainfall events with high, intermediate, and low temporal accuracy is $65(34.9 \%), 76(40.9 \%)$, and $45(24.2 \%)$, respectively. The events listed in the catalogue have rainfall durations in the range $1 \leq D \leq 451 \mathrm{~h}$ and cumulated event rainfall in the range $12.8 \leq E \leq 542.0 \mathrm{~mm}$. Fig. 3 shows the cumulated number and the frequency of the rainfall duration $D$, and of the cumulated event rainfall $E$, for the 186 rainfall events in the catalogue.

\subsection{Cumulated event rainfall - rainfall duration $(E D)$ regional thresholds}

The 186 blue dots in Fig. 4 portray the rainfall duration vs. cumulated event rainfall $(D, E)$ conditions that resulted in shallow landslides in Calabria in the investigated period. 
Table 1. Distribution of landslides in the five provinces of Calabria. The last three columns list the number of the landslides mapped for each geographical mapping accuracy class (see text).

\begin{tabular}{lrrrrrrrrr}
\hline \multirow{2}{*}{ Province } & \multicolumn{3}{c}{ Area } & \multicolumn{2}{c}{ Landslides } & $P_{1}$ & $P_{10}$ & $P_{100}$ \\
\cline { 2 - 10 } & & $\left(\mathrm{km}^{2}\right)$ & $(\%)$ & $(\#)$ & $\left(\#\right.$ per $\left.1000 \mathrm{~km}^{2}\right)$ & $(\%)$ & $(\#)$ & $(\#)$ & $(\#)$ \\
\hline Catanzaro & $\mathrm{CZ}$ & 2392 & 15.9 & 29 & 12.1 & 11.6 & 6 & 15 & 8 \\
Cosenza & $\mathrm{CS}$ & 6651 & 44.1 & 151 & 22.7 & 60.2 & 78 & 62 & 11 \\
Crotone & $\mathrm{KR}$ & 1718 & 11.4 & 10 & 5.8 & 4.0 & 6 & 3 & 1 \\
Reggio di Calabria & $\mathrm{RC}$ & 3180 & 21.1 & 38 & 11.9 & 15.1 & 13 & 20 & 5 \\
Vibo Valentia & $\mathrm{VV}$ & 1139 & 7.6 & 23 & 20.2 & 9.2 & 13 & 2 & 8 \\
\hline Total & & 15080 & 100.0 & 251 & 16.6 & 100.0 & 116 & 102 & 33 \\
\hline
\end{tabular}

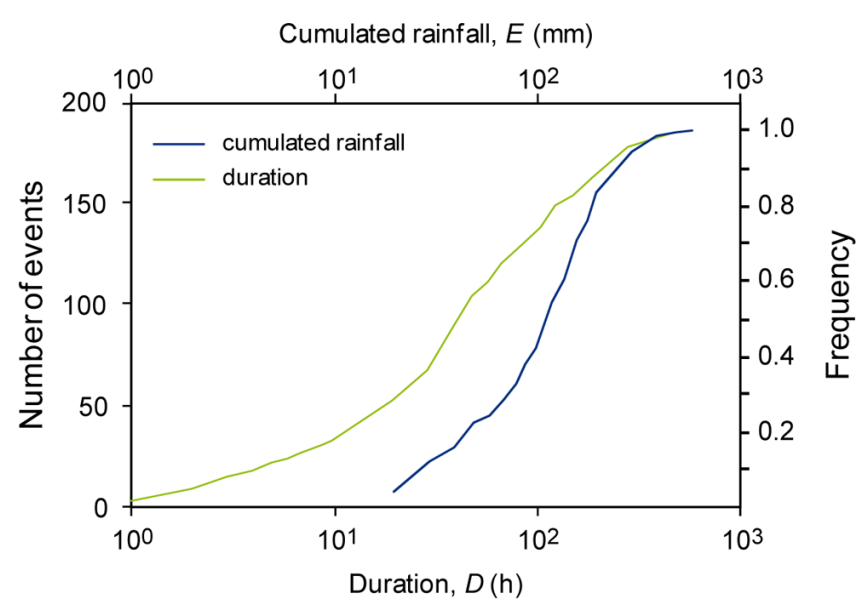

Fig. 3. Frequency curves of the rainfall duration $D$ (in hours) and the cumulated event rainfall $E$ (in $\mathrm{mm}$ ) for the 186 rainfall $(D, E)$ conditions that resulted in shallow landslides in Calabria in the 16year period from January 1996 to September 2011.

Visual inspection of the plot reveals that the empirical points are reasonably well distributed in the range of durations and cumulated event rainfall to allow for the definition of reliable thresholds (Brunetti et al., 2010; Peruccacci et al., 2012). In the plot, the blue line and the associated shaded area show the $5 \% E D$ threshold $\left(T_{5, \mathrm{C}}\right), E=(8.6 \pm 1.1) \cdot D^{(0.41 \pm 0.03)}$. Table 2 lists the equations and the uncertainties associated with the $1 \%\left(T_{1, \mathrm{C}}\right)$ and the $5 \%\left(T_{5, \mathrm{C}}\right) E D$ regional thresholds defined for Calabria.

We have analysed the uncertainty associated with the $E D$ regional thresholds (Fig. 5). The analysis was performed adopting the bootstrap non-parametric statistical technique proposed by Peruccacci et al. (2012). As expected, the variation in the mean values of the two parameters $\alpha$ and $\gamma$ that controls the power-law threshold curves, and the associated uncertainties ( $\Delta \alpha$ and $\Delta \gamma$ ), decreases when the number of events increases. The mean value of the scaling parameter converges to $\alpha=5.8$ for $T_{1, \mathrm{C}}$ and to $\alpha=8.6$ for $T_{5, \mathrm{C}}$ (Fig. 5a and c). Similarly, the mean value of the exponent of the power-law model converges rapidly to $\gamma=0.41$, for both

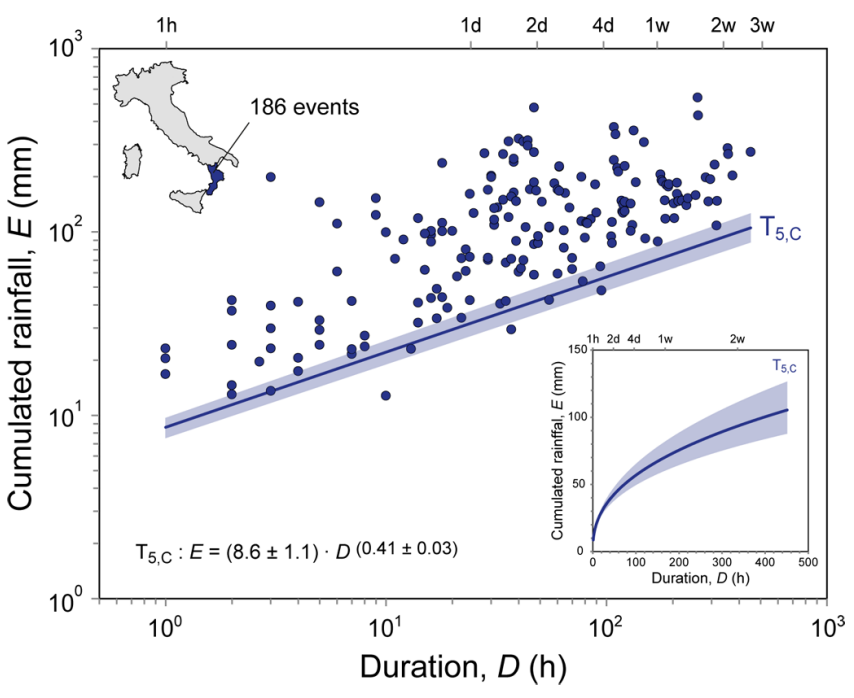

Fig. 4. Rainfall duration vs. cumulated event rainfall $(D, E)$ conditions that resulted in shallow landslides in Calabria (blue dots), and related $E D$ threshold at the $5 \%$ exceedance probability level. Inset shows the threshold in linear coordinates. Shaded areas show uncertainties associated with the threshold.

thresholds $T_{1, \mathrm{C}}$ and $T_{5, \mathrm{C}}$ (Fig. 5e). The uncertainties $\Delta \alpha$ and $\Delta \gamma$, represented by the error bars in Fig. 5a, c and e and by the square symbols in Fig. 5b, $\mathrm{d}$ and $\mathrm{f}$, decrease as the number of events increases. In particular, for $n<75$, the values of $\alpha$ have not yet converged to their limits. For $n \geq 75$, the average values of $\alpha$ and $\gamma$ do not vary significantly (e.g. $\alpha$ varies less than 0.2 ), but the uncertainties remain significant (e.g. for $n=186$ the relative uncertainties are $\Delta \alpha / \alpha=13.8 \%$ and $\Delta \gamma / \gamma=7.3 \%)$.

\subsection{Role of environmental factors}

To investigate the role of different environmental factors in the rainfall conditions responsible for shallow landslides in Calabria, we segmented the regional catalogue into different sub-sets. The segmentation was performed on (i) the main lithological domains, (ii) the soil regions, (iii) the rainfall 

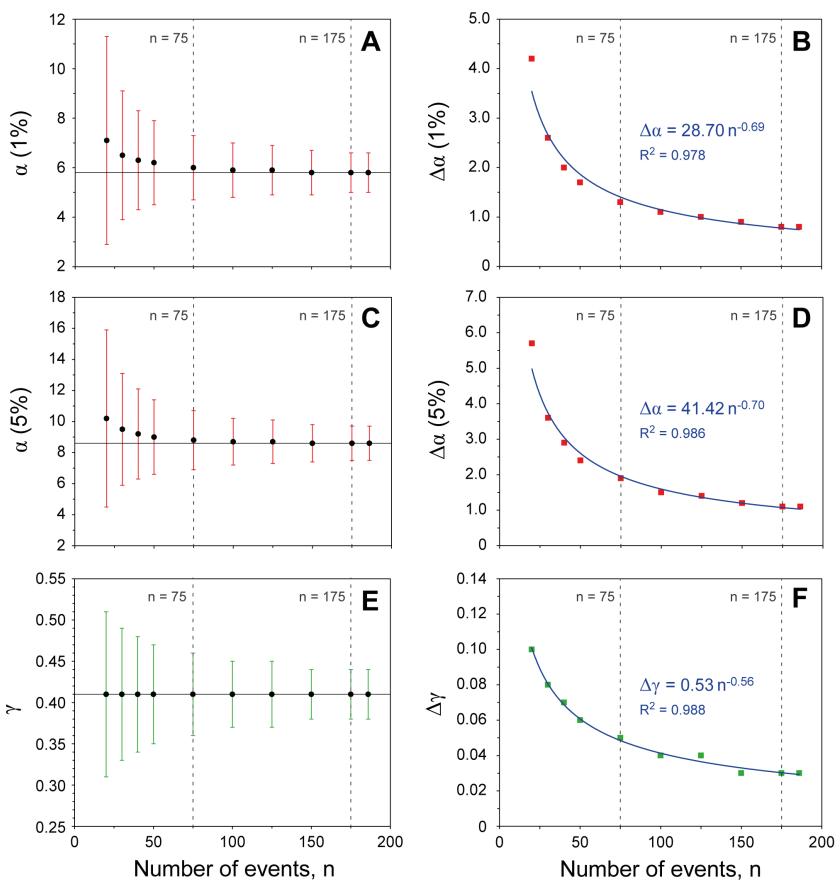

Fig. 5. Variation of the threshold model parameters $(\alpha$ and $\gamma)$ and of their uncertainties $(\Delta \alpha$ and $\Delta \gamma)$ as a function of the number of events $n$, for the $1 \%$ and the $5 \%$ exceedance probability levels. In the left plots, black dots show the average values of $\alpha(\mathbf{A}, \mathbf{C})$ and $\gamma$ (E), and the coloured bars show the relative variations. In the right plots, coloured squares represent the values of $\Delta \alpha(\mathbf{B}, \mathbf{D})$ and $\Delta \gamma$ (F), and the blue lines are best fits (linear regression method) to the empirical data.

regions, and on (iv) two seasonal periods. We further segmented the catalogue into administrative alert zones decided by the National Civil Protection Department for hydrometeorological operational forecasting and warning.

To attribute a landslide to a specific environmental class (e.g. a lithological type, soil region, rainfall region), the individual landslides originally mapped as points were transformed into circles, with the size (area) of the circle dependent on the geographical accuracy of each landslide. Specifically, the area of the circles was $A=0.5 \mathrm{~km}^{2}$ for landslides attributed a high level of accuracy $\left(P_{1}\right), A=5 \mathrm{~km}^{2}$ for landslides attributed a medium level of accuracy $\left(P_{10}\right)$, and $A=50 \mathrm{~km}^{2}$ for landslides attributed a low level of accuracy $\left(P_{100}\right)$. Next, the GIS layer containing the landslide circles was intersected with the individual layers representing the individual environmental factors, or the administrative subdivision, and the proportion of each class of terrain in the circle was computed. Only landslides for which at least $75 \%$ in a single environmental class was present in the representative circle were selected and used for the subsequent analyses. The selection was adopted to assign the prevalent environmental factor to each landslide (Peruccacci et al., 2012).

\subsubsection{Lithological domains}

Using the lithological map of Italy compiled by Compagnoni et al. (1976-1983) at 1:500000 scale, we partitioned the Calabria region into four broad lithological domains encompassing (Fig. 6a): (i) carbonate rocks (CC, $13.6 \%$ of the region), including limestone, dolomitic limestone, dolostone, hard sandstone, and conglomerate, (ii) flysch deposits (FD, $30.1 \%$ ), comprising marl, shale, evaporite, and very low- to low-grade metamorphic rocks, (iii) metamorphic and crystalline rocks (MC, 30.6\%), comprising medium- to highgrade metamorphic rocks (gneiss), intrusive rocks (granite, granodiorite), and ophiolites, and (iv) post-orogenic sediments (PO, $25.7 \%$ ), chiefly continental and marine clay, silt, sand, and gravel.

Intersection in the GIS of the landslide layer with the lithological layer (Fig. 6a) identified 142 landslides (56.5\%) for which at least $75 \%$ of the representative circle was attributed to a single (prevalent) lithological class, including: (i) 56 landslides $(39.4 \%)$ in the PO domain (14.4 landslides per $1000 \mathrm{~km}^{2}$ ), (ii) 49 landslides $(34.5 \%$ ) in the MC domain (10.6 landslides per $1000 \mathrm{~km}^{2}$ ), (iii) 24 landslides $(16.9 \%)$ in the FD domain (5.3 landslides per $1000 \mathrm{~km}^{2}$ ), and (iv) 13 landslides $(9.2 \%)$ in the CC domain (6.3 landslides per $1000 \mathrm{~km}^{2}$ ) (Table 3 ).

Figure 7a portrays the 119 rainfall $(D, E)$ conditions that resulted in the 142 shallow landslides in the four lithological domains. The reduced number of empirical data points in each lithological domain (11 for CC, 23 for FD, 39 for MC, and 46 for PO) was insufficient to determine reliable thresholds. However, significant differences are not evident in the distribution and the general trend of the $(D, E)$ data points, for the four lithological domains. Inspection of Fig. 7a shows that the rainfall conditions responsible for landslides in the $\mathrm{MC}$ and PO lithological domains cover the entire range of rainfall durations, ranging from a few hours to several days $(1 \leq D \leq 357 \mathrm{~h})$, whereas the conditions that caused landslides in the FD and CC domains are more numerous for durations $D>10 \mathrm{~h}$. The apparent lack of events for short rainfall durations is probably due to the reduced number of events collected in the two FD and CC domains. The shape (e.g. dispersion and general shape) of the distribution of $(D, E)$ pairs for each lithological domain has to be confirmed by collecting a larger number of events.

\subsubsection{Soil regions}

The Calabria Regional Agency for the Development and Services in Agriculture published a soil map of Calabria, at $1: 250000$ scale (Fig. 6b) (ARSSA, 2003). The map shows four soil regions characterized by distinct morphological, lithological, climatic, and soil properties, including: (i) the Pollino range and the neighbouring hills (SR1, $7.8 \%$ of the region), comprising mountains and hills where carbonate rock crops out and climate is Mediterranean, (ii) the northern 
Table 2. Rainfall ED thresholds for shallow landslides in Calabria, in other areas in Italy, and globally. Number lists the number of rainfall events used to define the threshold. Source: 1 to 6, this work; 7, Peruccacci et al. (2012); 8, Brunetti et al. (2013); 9, Innes (1983); 10, Kanji et al. (2003).

\begin{tabular}{rllrlll}
\hline Source & Label & Area & Number & Equation & Validity range (h) & Uncertainty \\
\hline 1 & $T_{1, \mathrm{C}}$ & Calabria & 186 & $E=5.8 \cdot D^{0.41}$ & $1 \leq D \leq 451$ & $\Delta \alpha=0.8, \Delta \gamma=0.03$ \\
2 & $T_{5, \mathrm{C}}$ & Calabria & 186 & $E=8.6 \cdot D^{0.41}$ & $1 \leq D \leq 451$ & $\Delta \alpha=1.1, \Delta \gamma=0.03$ \\
3 & $T_{1, \mathrm{TAR}}$ & Tyrrhenian Alert Region & 117 & $E=6.7 \cdot D^{0.36}$ & $1 \leq D \leq 451$ & $\Delta \alpha=1.1, \Delta \gamma=0.04$ \\
4 & $T_{5, \mathrm{TAR}}$ & Tyrrhenian Alert Region & 117 & $E=9.7 \cdot D^{0.36}$ & $1 \leq D \leq 451$ & $\Delta \alpha=1.5, \Delta \gamma=0.04$ \\
5 & $T_{1, \mathrm{IAR}}$ & Ionian Alert Region & 69 & $E=6.3 \cdot D^{0.50}$ & $1 \leq D \leq 357$ & $\Delta \alpha=1.4, \Delta \gamma=0.05$ \\
6 & $T_{5, \mathrm{IAR}}$ & Ionian Alert Region & 69 & $E=9.0 \cdot D^{0.50}$ & $1 \leq D \leq 357$ & $\Delta \alpha=1.8, \Delta \gamma=0.05$ \\
\hline 7 & $T_{5, \mathrm{AMU}}$ & Abruzzo, Marche, Umbria & 442 & $E=7.4 \cdot D^{0.38}$ & $1 \leq D \leq 1212$ & $\Delta \alpha=0.5, \Delta \gamma=0.02$ \\
8 & $T_{5, \mathrm{Cal}}$ & Calabria & 113 & $E=7.85 \cdot D^{0.43}$ & $1 \leq D \leq 1080$ & n.a. \\
\hline 9 & Innes & Global threshold & 35 & $E=4.9355 \cdot D^{0.5041}$ & $0.2 \leq D \leq 100$ & n.a. \\
10 & Kanji & Global threshold & n.a. & $E=22.4 \cdot D^{0.41}$ & n.a. & n.a. \\
\hline
\end{tabular}

Ionian coastal zone (SR2, $4.1 \%$ ), comprising hills, coastal plains, and piedmont zones underlined by flysch rocks and where the climate is mountainous Mediterranean, (iii) the coastal hills and plains (SR3, 50.2\%), comprising alluvial and coastal plains and hills where the bedrock consists of sediments Tertiary to Quaternary in age, and the climate is sub-continental to sub-tropical Mediterranean, and (iv) the Sila, Serre, and Aspromonte ranges (SR4, $37.9 \%$ ), comprising mountains, hills, and minor internal plains where the bedrock consists of crystalline and metamorphic rocks, and the climate is mountainous Mediterranean (ARSSA, 2003).

Intersection in the GIS of the landslide layer with the soil map (Fig. 6b) singled out 199 landslides (79.3\%) for which at least $75 \%$ of the representative circle was attributed to a single (prevalent) soil class, including: (i) 130 landslides $(65.3 \%)$ in the SR3 soil region (17.2 landslides per $1000 \mathrm{~km}^{2}$ ), (ii) 57 landslides (28.6\%) in the SR4 region (10 landslides per $1000 \mathrm{~km}^{2}$ ), and (iii) 12 landslides $(6 \%)$ in the SR1 region (10.2 landslides per $1000 \mathrm{~km}^{2}$ ) (Table 3). No landslides were identified in the SR2 soil region, limited to the NE part of the study area (Fig. 6b).

Figure $7 \mathrm{~b}$ portrays the 157 rainfall $(D, E)$ conditions that produced 199 shallow landslides in the three soil regions. As for the lithological domains, the number of empirical data points in each soil region was insufficient for a reliable determination of specific rainfall thresholds. For the SR1 and SR3 soil regions, Fig. 7b shows minor differences in the distribution of the empirical data points. Rainfall conditions in the SR1 soil align along a straight line (power law) with a very low dispersion. However, this may be an artefact due to the very reduced number of data points in this soil region (9). We conclude that rainfall conditions for landslide occurrence in the three soil regions for Calabria cannot be discriminated, with the available data.

\subsubsection{Rainfall regions}

For operational flood forecasting and hazard assessment, Versace et al. (1989) analysed the annual maxima of highintensity, short-duration rainfall events in Calabria, and identified three homogeneous rainfall regions (Fig. 6c), including: (i) a Tyrrhenian region (T, $25.8 \%$ of the region) along the western Tyrrhenian coast, (ii) a Central region (C, 44.3\%), comprising the mountain ranges along the main divide, and (iii) an Ionian region, along the eastern Ionian coast (I, $29.9 \%$ ). They found that the Tyrrhenian rainfall region is characterized by more frequent and less severe rainfall events than the Ionian rainfall region, whereas the Central rainfall region has events with intermediate characteristics. Short and very intense events are more frequent on the Ionian side of Calabria (Terranova and Iaquinta, 2011).

Intersection in the GIS of the landslide layer with the map showing the three rainfall regions (Fig. 6c) recognized 212 landslides $(84.5 \%)$ for which at least $75 \%$ of the representative circle was attributed to a prevalent rainfall region, including: (i) 117 landslides (55.2\%) in the Tyrrhenian region (17.5 landslides per $1000 \mathrm{~km}^{2}$ ), (ii) 63 landslides $(29.7 \%$ ) in the Central region $\left(16.2\right.$ landslides per $\left.1000 \mathrm{~km}^{2}\right)$, and (iii) 32 landslides $(15.1 \%)$ in the Ionian region (7.1 landslides per $1000 \mathrm{~km}^{2}$ ) (Table 3).

Figure $7 \mathrm{c}$ shows the 158 rainfall $(D, E)$ conditions responsible for the 212 shallow landslides in the three rainfall geographical subdivisions. Again, the number of empirical points in each rainfall region was insufficient to establish sound thresholds for the individual regions. Inspection of Fig. 7c shows that the rainfall conditions responsible for landslides in the Ionian (I) and in the Central (C) regions are more abundant than the rainfall events in the Tyrrhenian region (T). This is a consequence of the spatial distribution of rainfall events in the catalogue. Inspection of Table 1 reveals that about $60 \%$ of the events ( 151 over 251$)$ is located in 
Table 3. Descriptive statistics for landslides and for the corresponding rainfall events in Calabria in the period January 1996-September 2011. Rows: RE, number of rainfall events; LE, number of landslide events; $D$, rainfall duration (hours); $E$, cumulated event rainfall (mm); $I$, rainfall mean intensity $\left(\mathrm{mm} \mathrm{h}^{-1}\right)$. Columns: $\mathrm{CC}$, carbonate rocks; FD, flysch deposits; MC, metamorphic and crystalline rocks; PO, postorogenic sediments; SR1, Pollino range and the neighbouring hills; SR2, northern Ionian coastal zone; SR3, coastal hills and plains; SR4, Sila, Serre and Aspromonte ranges; T, Tyrrhenian rainfall region; C, Central rainfall region; I, Ionian rainfall region; TAR, Tyrrhenian alert region; IAR, Ionian alert region; A-O, April-October seasonal period; N-M, November-March seasonal period.

\begin{tabular}{|c|c|c|c|c|c|c|c|c|c|c|c|c|}
\hline & \multirow{2}{*}{$\begin{array}{c}\text { Extent } \\
\left(\mathrm{km}^{2}\right)\end{array}$} & \multirow{2}{*}{$\mathrm{RE}$} & \multirow{2}{*}{ LE } & \multicolumn{3}{|c|}{$D(\mathrm{~h})$} & \multicolumn{3}{|c|}{$E(\mathrm{~mm})$} & \multicolumn{3}{|c|}{$I\left(\mathrm{~mm} \mathrm{~h}^{-1}\right)$} \\
\hline & & & & Min & Max & Mean & Min & $\operatorname{Max}$ & Mean & Min & Max & Mean \\
\hline Calabria & 15080 & 186 & 251 & 1 & 1128 & 98.9 & 12.8 & 542.0 & 135.9 & 0.30 & 66.40 & 4.30 \\
\hline \multicolumn{13}{|c|}{ Lithological domains } \\
\hline $\mathrm{CC}$ & 2054 & 11 & 13 & 7 & 451 & 75.4 & 42.0 & 273.6 & 136.2 & 0.61 & 9.58 & 4.32 \\
\hline FD & 4514 & 23 & 24 & 2 & 310 & 101.0 & 13.0 & 542.0 & 187.0 & 0.75 & 7.41 & 2.90 \\
\hline MC & 4618 & 39 & 49 & 1 & 357 & 75.1 & 12.8 & 477.6 & 135.2 & 0.63 & 29.04 & 4.68 \\
\hline $\mathrm{PO}$ & 3894 & 46 & 56 & 1 & 451 & 68.2 & 16.8 & 312.4 & 98.4 & 0.34 & 66.40 & 7.05 \\
\hline Total & 15080 & 119 & 142 & & & & & & & & & \\
\hline \multicolumn{13}{|c|}{ Soil regions } \\
\hline SR1 & 1175 & 9 & 12 & 2 & 176 & 55.7 & 24.2 & 206.3 & 82.7 & 1.11 & 12.10 & 4.45 \\
\hline SR2 & 618 & 0 & 0 & & & & & & & & & \\
\hline SR3 & 7575 & 102 & 130 & 1 & 451 & 82.3 & 13.0 & 542.0 & 131.9 & 0.34 & 23.20 & 4.30 \\
\hline SR4 & 5712 & 46 & 57 & 1 & 357 & 81.5 & 12.8 & 477.6 & 157.4 & 0.63 & 20.44 & 4.03 \\
\hline Total & 15080 & 157 & 199 & & & & & & & & & \\
\hline \multicolumn{13}{|c|}{ Rainfall regions } \\
\hline $\mathrm{T}$ & 6681 & 81 & 117 & 1 & 451 & 90.3 & 12.8 & 309.4 & 98.5 & 0.30 & 451.0 & 90.3 \\
\hline $\mathrm{C}$ & 3886 & 49 & 63 & 1 & 290 & 54.4 & 13.6 & 477.6 & 148.5 & 0.51 & 29.04 & 6.10 \\
\hline I & 4513 & 28 & 32 & 2 & 282 & 78.4 & 13.0 & 542.0 & 196.4 & 0.50 & 18.53 & 4.77 \\
\hline Total & 15080 & 158 & 212 & & & & & & & & & \\
\hline \multicolumn{13}{|c|}{ Dry/wet seasonal periods } \\
\hline $\mathrm{A}-\mathrm{O}$ & & 60 & 80 & 1 & 290 & 38.1 & 13.0 & 542.0 & 106.3 & 0.50 & 66.40 & 7.30 \\
\hline $\mathrm{N}-\mathrm{M}$ & & 126 & 171 & 3 & 451 & 98.4 & 12.8 & 433.0 & 141.2 & 0.34 & 29.04 & 3.06 \\
\hline Total & & 186 & 251 & & & & & & & & & \\
\hline \multicolumn{13}{|c|}{ Alert regions } \\
\hline TAR & 6122 & 117 & 157 & 1 & 451 & 82.9 & 12.8 & 357.4 & 109.0 & 0.30 & 66.40 & 4.10 \\
\hline IAR & 8958 & 69 & 88 & 1 & 357 & 72.5 & 13.0 & 542.0 & 163.8 & 0.50 & 20.40 & 5.06 \\
\hline Total & 15080 & 186 & 245 & & & & & & & & & \\
\hline
\end{tabular}

the northern part of the region (in Cosenza Province), where the Ionian area is smaller than the Tyrrhenian and the Central areas. Figure $7 \mathrm{c}$ shows that, on average, the rainfall $(D, E)$ conditions that triggered landslides in the Tyrrhenian region are less severe than the conditions that cause landslides in the Ionian and Central regions.

\subsubsection{Dry and wet seasonal periods}

In Calabria, the climate is Mediterranean with distinct dry and wet seasonal periods. To investigate the dependence of the rainfall events on the seasonal rainfall conditions, we have segmented the catalogue into two seasonal periods: (i) a wet period from November to March $(\mathrm{N}-\mathrm{M})$, and (ii) a dry period from April to October (A-O). Of the 186 rainfall $(D, E)$ conditions in the catalogue, $67.7 \%$ are in the wet $(\mathrm{N}-\mathrm{M})$ period, and $32.3 \%$ in the dry $(\mathrm{A}-\mathrm{O})$ period (Fig. 8 , Table 3). Rainfall events in the $\mathrm{N}-\mathrm{M}$ period have durations ranging from a few hours to several days $(3 \leq D \leq 451 \mathrm{~h}$, $\bar{D}=98 \mathrm{~h})$, and low rainfall mean intensities $\left(\bar{I}=3 \mathrm{~mm} \mathrm{~h}^{-1}\right)$. Conversely, events in the A-O period exhibit shorter durations ( $1 \leq D \leq 290 \mathrm{~h}, \bar{D}=38 \mathrm{~h}$ ) and higher mean intensities $\left(\bar{I}=7.3 \mathrm{~mm} \mathrm{~h}^{-1}\right)$. In detail, $65 \%$ of the events that occurred 


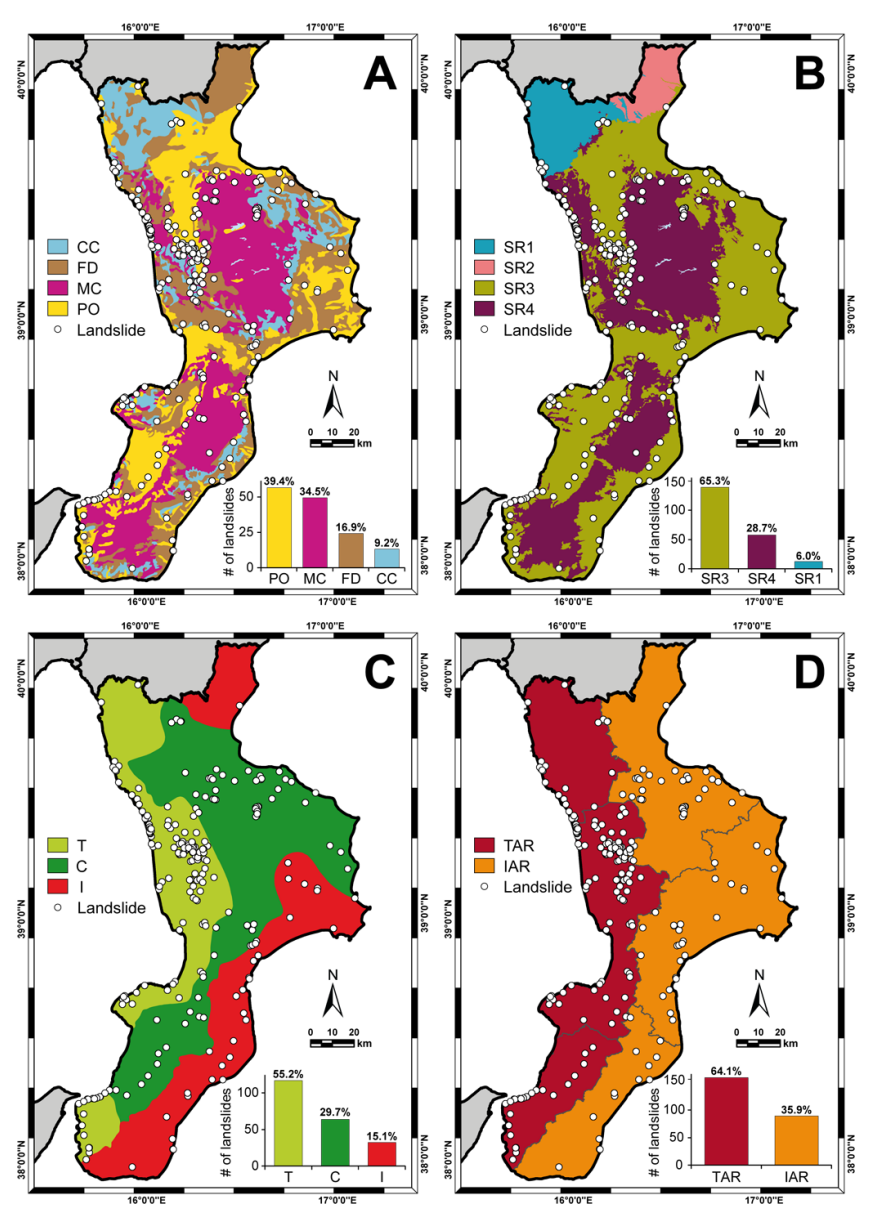

Fig. 6. Geographical distribution of shallow rainfall-induced landslides (white dots) in Calabria, in the 16-year period from January 1996 to September 2011, superimposed on maps of different environmental factors. Histograms show the number and the proportion of shallow landslides for each factor class. (A) Lithological domains: CC, carbonate rocks; FD, flysch deposits; MC, metamorphic and crystalline rocks; PO, post-orogenic sediments. (B) Soil regions: SR1, Pollino range and neighbouring hills; SR2, northern Ionian coastal zone; SR3, coastal hills and plains; SR4, Sila, Serre and Aspromonte ranges. (C) Rainfall regions: T, Tyrrhenian region; C, Central region; I, Ionian region. (D) Civil Protection alert regions: TAR, Tyrrhenian alert region; IAR, Ionian alert region.

in the dry (A-O) period are characterised by rainfall durations not exceeding $24 \mathrm{~h}$, and $75 \%$ of the events in the wet $(\mathrm{N}-\mathrm{M})$ period have durations longer than $24 \mathrm{~h}$. The average number of rainfall events per month is 25.2 for the $\mathrm{N}-\mathrm{M}$ period, and 8.6 for the A-O period. Rainfall events with landslides are most frequent in January (43) and are rare in July (4).

Figure 8 shows the rainfall $(D, E)$ conditions for 126 events in the wet (N-M) period (grey dots), and for 60 events in the dry (A-O) period (blue dots). For both periods, the number of rainfall events was insufficient to determine reliable thresholds for the two seasonal subdivisions.
Nonetheless, differences exist in the distribution and the general trend of the $(D, E)$ empirical data points, for the considered seasonal periods. In Calabria, most of the rainfall events that resulted in landslides and are listed in the catalogue occurred in winter $(53.8 \%)$ and in autumn $(20.0 \%)$, with $23.5 \%$ of the events in January and $19.1 \%$ in December. The remaining events occurred in spring $(15.1 \%)$ and in summer $(11.1 \%)$, with $10.4 \%$ of the events in September $(10.4 \%)$. The result is in agreement with the outcomes of an historical analysis of 2982 historical rainfall-induced landslides in Calabria between 1921 and 2006 that revealed that $67 \%$ of the landslides occurred in the 4-month period between November and February (Polemio and Petrucci, 2010). The distribution of the event duration in the two periods is different. The majority of rainfall events with landslides in the A-O period are characterised by durations $D<10 \mathrm{~h}$, while in the $\mathrm{N}-\mathrm{M}$ period in most of the triggering conditions $D>10 \mathrm{~h}$. This result is in agreement with the results obtained by Peruccacci et al. (2012) for the Abruzzo, Marche and Umbria regions of central Italy.

\subsection{Sub-regional thresholds for shallow landslide forecasting}

For hydro-meteorological monitoring and operational flood forecasting, the Italian national Department for Civil Protection has divided the national territory into 134 alert zones, based on administrative boundaries and regional hydrometeorological conditions. The subdivision partitions Calabria into six alert zones, three along the Tyrrhenian coast and three along the Ionian coast (Fig. 6d). The number of rainfall events with landslides in each division was insufficient to establish reliable rainfall thresholds for the individual alert zones. Thus, considering the general hydrometeorological characteristics in the alert zones (Terranova, 2003, 2004; Terranova et al., 2013), we grouped the six alert zones into two broad alert regions (Fig. 6d), including: (i) a Tyrrhenian alert region (59.4\% of the total area), comprising the three alert zones along the Tyrrhenian coast, and (ii) an Ionian alert region ( $40.6 \%$ of the total area), comprising the three alert zones along the Ionian coast. Intersection in the GIS of the landslide layer with the map showing the two alert regions (Fig. 6d) assigned 245 landslides (97.6\%) to an alert region, including: (i) 157 landslides $(64.1 \%)$ to the Tyrrhenian alert region (25.6 landslides per $1000 \mathrm{~km}^{2}$ ), and (ii) 88 landslides $(35.9 \%)$ to the Ionian alert region (9.8 landslides per $1000 \mathrm{~km}^{2}$ ) (Table 3).

Figure $7 \mathrm{~d}$ shows the 186 rainfall $(D, E)$ conditions responsible for 245 shallow landslides in the two alert regions. The ranges of rainfall duration in the two alert regions are similar, $1 \leq D \leq 357 \mathrm{~h}$ for the Ionian alert region, and $1 \leq D \leq 451 \mathrm{~h}$ for the Tyrrhenian alert region. The landslidetriggering rainfall events in the Ionian alert region have, on average, a shorter duration and larger cumulated event rainfall than the events in the Tyrrhenian alert region. No 

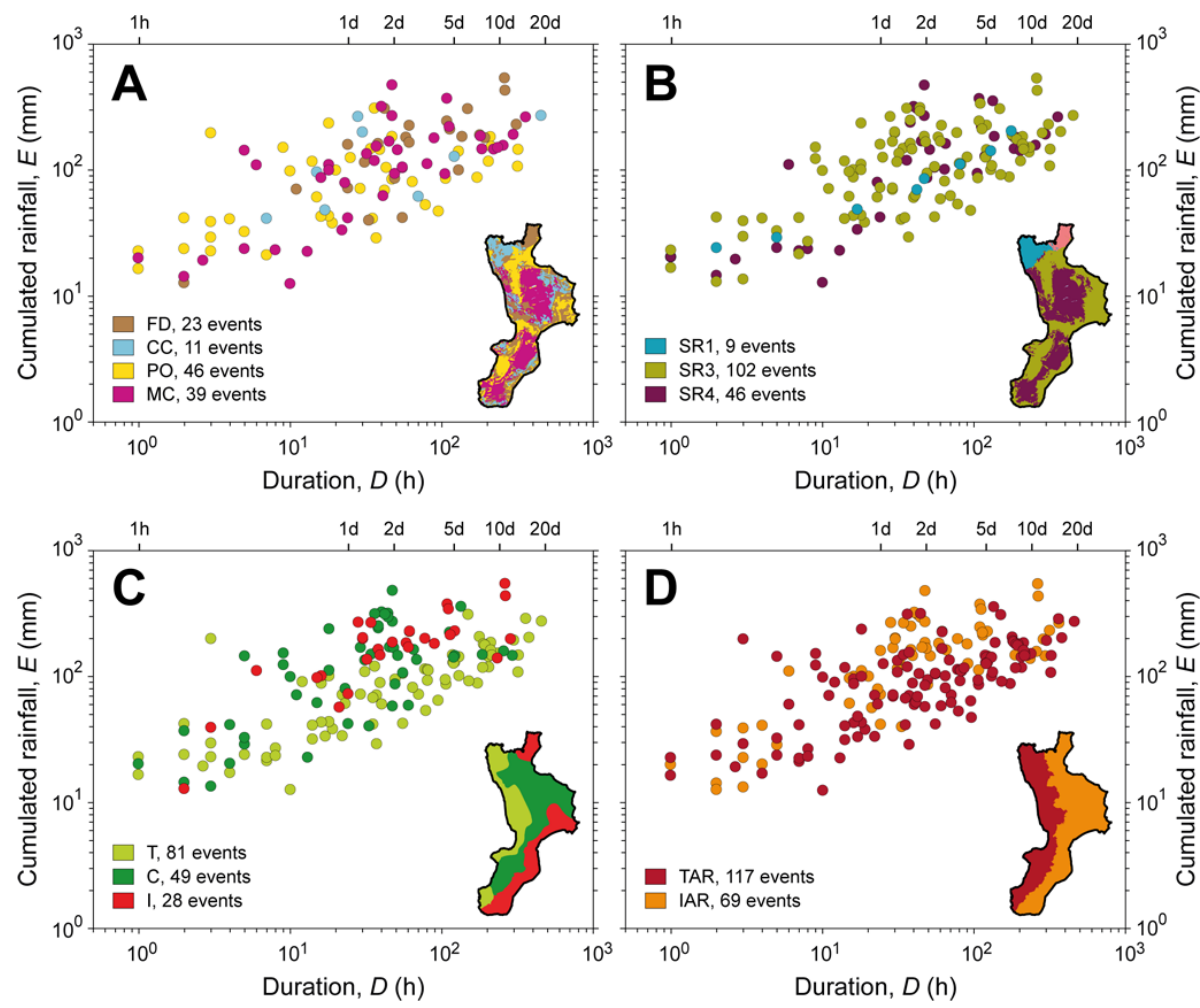

Fig. 7. Rainfall duration vs. cumulated event rainfall $(D, E)$ conditions that resulted in shallow landslides in Calabria for different environmental factors. (A) Four lithological domains. (B) Four soil regions. (C) Three rainfall regions. (D) Two Civil Protection alert regions. See Fig. 6 for location of the environmental factors and for colour legends.

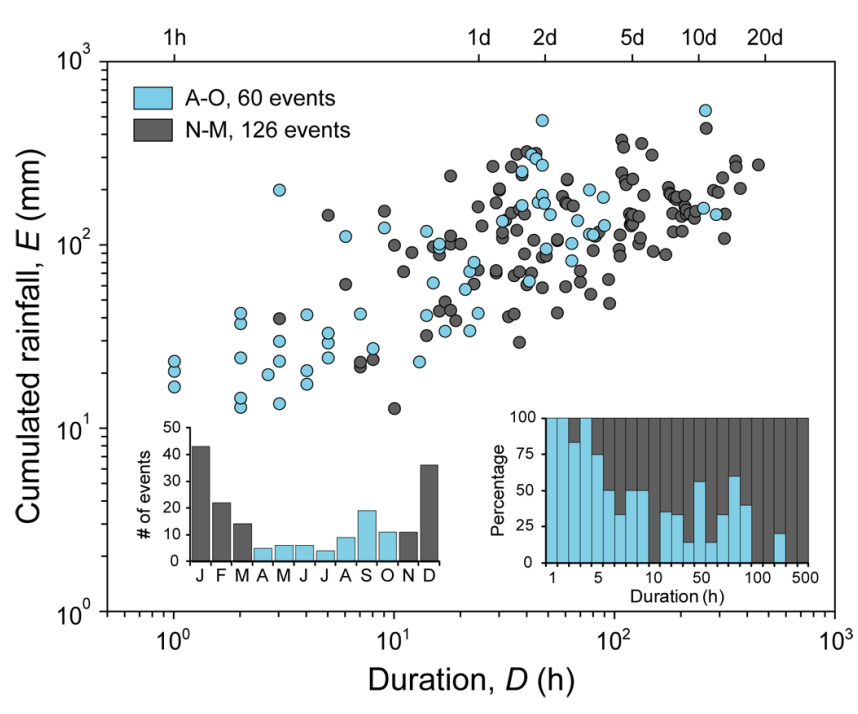

Fig. 8. Rainfall duration vs. cumulated event rainfall $(D, E)$ conditions that resulted in shallow landslides in Calabria between January 1996 and September 2011 for the April-October seasonal period (A-O, light blue dots) and for the November-March seasonal period (N-M, dark grey dots). Bar charts show the number of events per month (left), and the percentage of events for different durations (right), for the two periods. significant difference exists for the duration of the events in the two alert regions (Table 3, Fig. 9a and b). In the Ionian region, rainfall events responsible for landslides are more frequent in September and from December to January, whereas in the Tyrrhenian alert region the events that resulted in landslides were more abundant between December and March (Fig. 9c).

Figure 10 portrays the 186 rainfall $(D, E)$ conditions that produced 245 shallow landslides in the two alert regions. Despite the limited number of empirical data points, we determined the rainfall thresholds for the possible occurrence of shallow landslides for the Tyrrhenian alert region $\left(T_{1, \text { TAR }}\right.$ and $\left.T_{5, \mathrm{TAR}}\right)$ and for the Ionian alert region $\left(T_{1, \mathrm{IAR}}\right.$ and $\left.T_{5, \mathrm{IAR}}\right)$ (Table 2). Inspection of Fig. 10 reveals that the $T_{5, \text { IAR }}$ threshold defined for the Ionian region is steeper than the similar $T_{5, \mathrm{TAR}}$ threshold established for the Tyrrhenian region. For rainfall durations exceeding one day, $D>24 \mathrm{~h}$, the two thresholds are statistically different (i.e. their uncertainties do not overlap completely). We conclude that for rainfall events exceeding one day, lower amounts of cumulated event rain are required to trigger landslides in the Tyrrhenian alert region than in the Ionian alert region. 

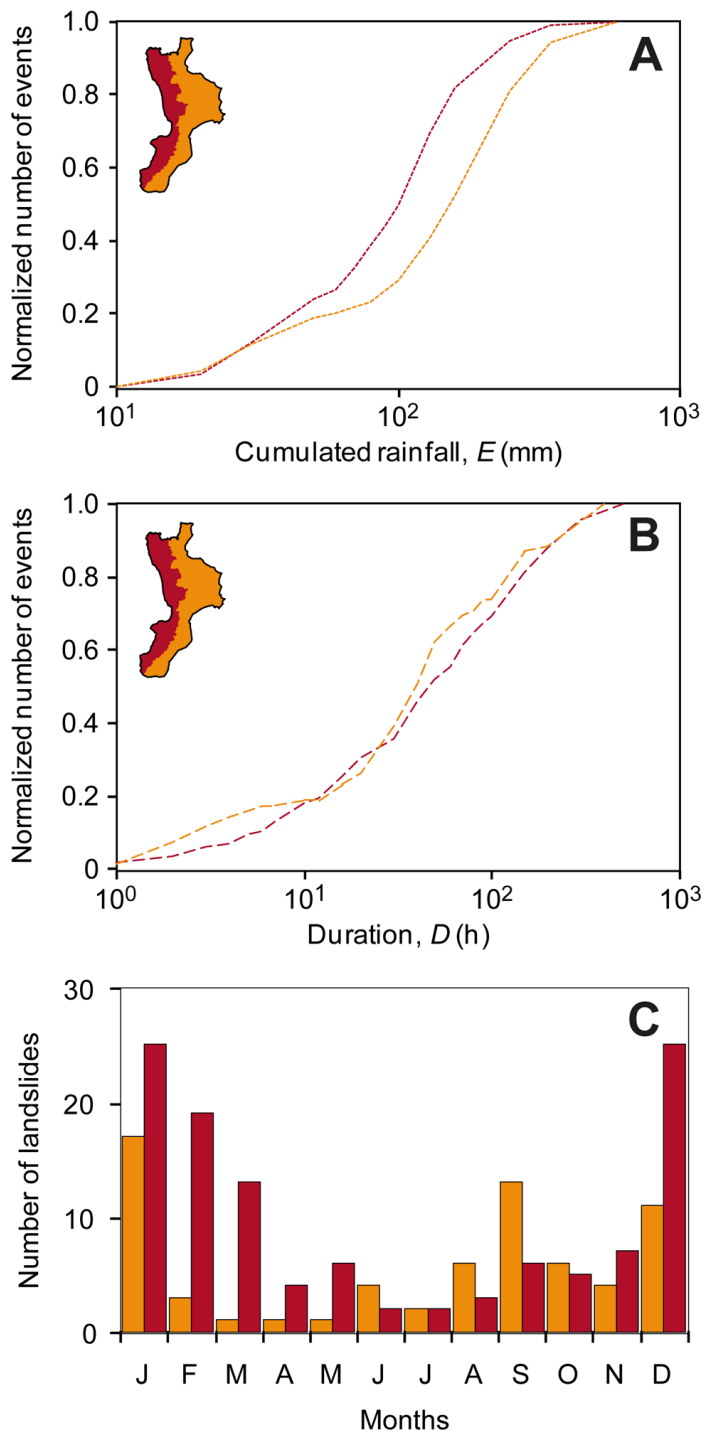

Fig. 9. Frequency of (A) the cumulated event rainfall and (B) the duration of the events, for the Tyrrhenian and the Ionian alert regions. (C) Monthly distribution of landslides in the two alert regions.

\section{Discussion}

Our catalogue lists 186 rainfall events that resulted in 251 shallow landslides in Calabria in the 16-year period from January 1996 to September 2011 (Fig. 2). This is an average frequency of 11.8 landslide-triggering rainfall events per year. The figure compares to 52.0 landslide-triggering rainfall events per year found by Peruccacci et al. (2012) for the Abruzzo, Marche and Umbria regions, central Italy. Peruccacci and her co-workers used the same strategy and similar sources of landslide and rainfall information used in this study. Considering that Calabria covers about half the area covered by the Abruzzo, Marche and Umbria regions $\left(15080 \mathrm{~km}^{2}\right.$ vs. $\left.28950 \mathrm{~km}^{2}\right)$, the density of events (\# of events per year per square kilometre) for Calabria is less

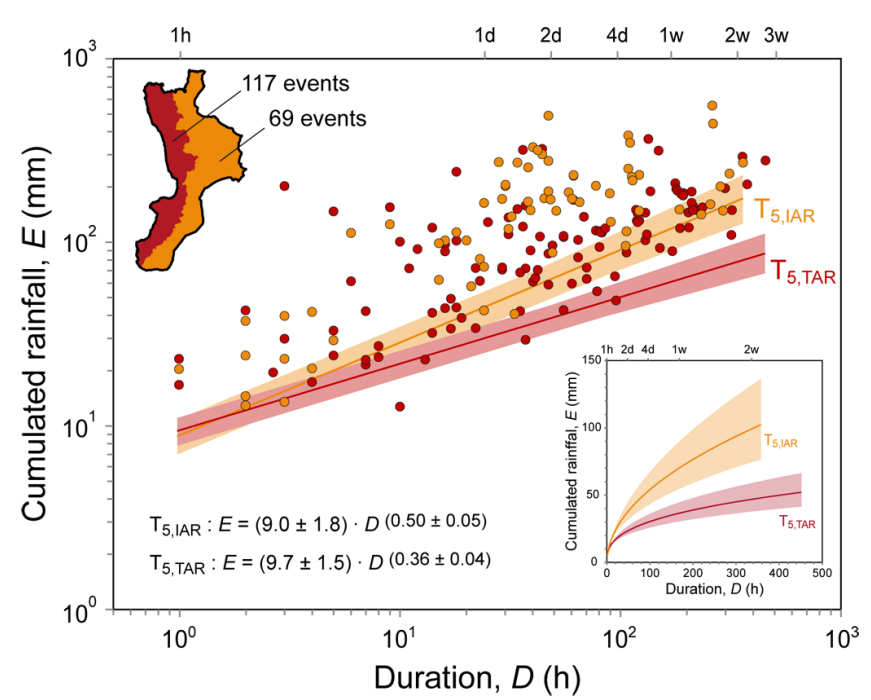

Fig. 10. Rainfall duration vs. cumulated event rainfall $(D, E)$ conditions that resulted in shallow landslides in Calabria in the Ionian alert region (orange dots) and in the Tyrrhenian alert region (red dots), and related $E D$ thresholds at the $5 \%$ exceedance probability levels $\left(\mathrm{T}_{5, \mathrm{IAR}}\right.$ and $\left.\mathrm{T}_{5, \mathrm{TAR}}\right)$. Inset shows the thresholds in linear coordinates. Shaded areas show uncertainties associated with the thresholds.

than half of the density of events for central Italy. The difference is conditioned by the availability of information used to compile the catalogues, and by the criteria adopted to determine the rainfall conditions that resulted in landslides. The difference cannot be used to measure climatic, meteorological, geomorphological or other physiographical differences, or to infer differences in landslide vulnerability or risk in the study areas.

The empirical $(D, E)$ data collected for Calabria were sufficient to determine regional $E D$ rainfall thresholds for possible landslide occurrence in the region, for different exceedance probability levels (Fig. 4). However, the evaluation of the relative uncertainty associated with the thresholds revealed that the uncertainties were significant. Peruccacci et al. (2012), working in central Italy, considered acceptable values of the relative uncertainty less than $10 \%$ that they reached for a number of empirical data points $n=175$. Based on this evidence, they concluded that 175 well-distributed $(D, E)$ empirical points were sufficient to estimate reliable rainfall thresholds. In Calabria, the relative uncertainty obtained using the entire set of 186 events is larger than $10 \%$, at least for the scaling parameter $\alpha(\Delta \alpha / \alpha=13.8 \%)$. This suggests that the minimum number of empirical data points necessary to determine reliable rainfall thresholds varies regionally. Variations depend on the shape of the distribution (e.g. data scattering around the mean tendency line, slope of the line). 
For a $1 \%(5 \%)$ threshold, $1 \%(5 \%)$ of the empirical $(D, E)$ data points should be below the threshold (Brunetti et al., 2012). In the regional data set for Calabria, only one empirical point $(0.5 \%)$ is below the $T_{1, \mathrm{C}}$ threshold, and five points $(2.7 \%)$ are below the $T_{5, \mathrm{C}}$ threshold. These percentages are lower than expected (i.e. $1 \%$ and $5 \%$, respectively). The result is directly related to the statistical technique used to determine the thresholds, and to the lack of symmetry in the distribution of the empirical $(D, E)$ points around their mean tendency line. The asymmetry may be an artefact due to the (relatively) limited number of empirical data, or it may reflect a specific characteristic of the landslide-triggering rainfall events in Calabria. More empirical data are needed to resolve this ambiguity.

Most of the landslides triggered by the 186 rainfall events listed in the catalogue were shallow failures, and they occurred in post-orogenic sediments (PO lithological domain) and where metamorphic and crystalline rocks (MS lithological domain) crop out. We attribute the large density of landslides in the PO lithological domain $(39.4 \%, 14.4$ failures per $1000 \mathrm{~km}^{2}$ ) to the poor geotechnical properties of the continental and marine sediments in this domain, and subordinately to the local terrain conditions (e.g. steep slopes). We explain the large proportion of events in the metamorphic and crystalline rocks $\left(34.5 \%, 10.6\right.$ failures per $\left.1000 \mathrm{~km}^{2}\right)$ with the abundance of weathered materials mantling the bedrock in this domain. For short duration rainfall events $(D \leq 24 \mathrm{~h})$, a smaller amount of rainfall is necessary to trigger landslides in the metamorphic and the crystalline rocks, compared to the post-orogenic sediments. For longer duration events $(D>24 \mathrm{~h})$ the trend is reversed, and landslides in metamorphic and crystalline rocks require more rain than in the post-orogenic sediments to occur. We attribute the large abundance of landslides in the coastal hills and plains soil region (SR3, 50.2\%) to the peculiar setting of the region, where soft sediments, Tertiary to Quaternary in age, crop out. Landslides were more abundant in the Tyrrhenian rainfall region than in the Central and the Ionian regions, and the amount of rainfall needed to trigger the failures in the Ionian region was higher than in the Central and in the Tyrrhenian regions. Most of the landslides listed in the catalogue occurred in the wet period between November and March (in particular, in January and December) and were triggered by short duration rainfall events with $D>10 \mathrm{~h}$. Further analysis revealed that, in Calabria, shallow landslides are more frequent in clay, silt, sand, and gravel deposits (PO lithological domain). In this domain, the failures occur primarily in the SR3 soil region (coastal hills and plains) of the Tyrrhenian rainfall region, between November and March. Conversely, shallow landslides are less frequent where marl, shale, evaporites, and very low- to low-grade metamorphic rocks crop out (FD lithological domain). In this domain, the failures are more rare in the Ionian rainfall region, and in the seasonal period between March and May.

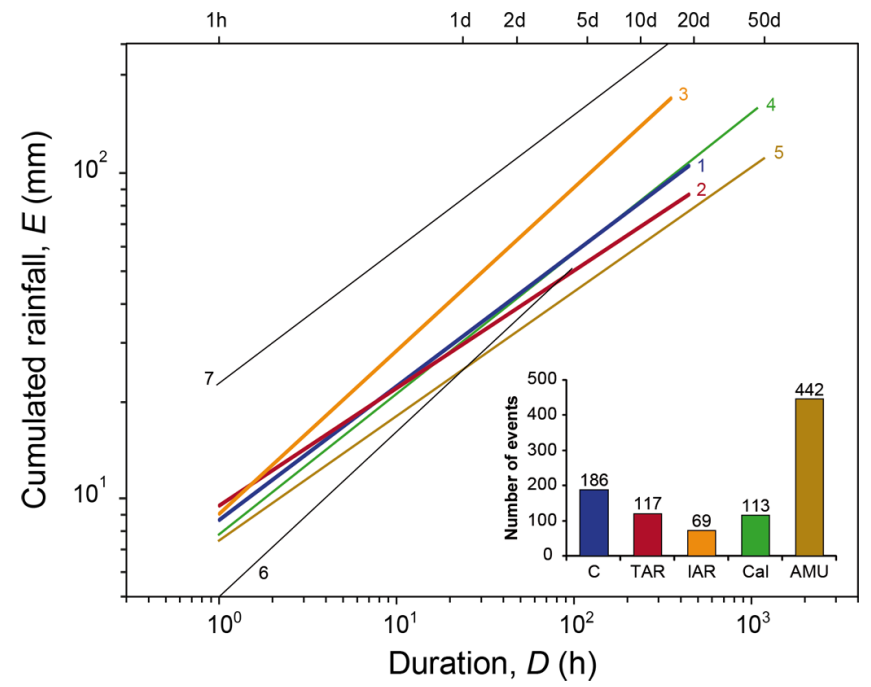

Fig. 11. Cumulated event rainfall - rainfall duration $(E D)$ thresholds for shallow landslides in Calabria: $T_{5, \mathrm{C}}$ (line 1), $T_{5, \mathrm{TAR}}$ (line 2),

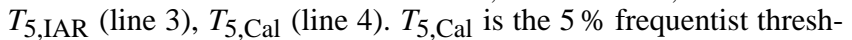
old proposed for Calabria by Brunetti et al. (2013). $T_{5, \mathrm{AMU}}$ (line 5 ) is the $5 \%$ frequentist threshold proposed for Abruzzo, Marche and Umbria (central Italy) by Peruccacci et al. (2012). Black line 6 is the global threshold for debris flow occurence of Innes (1983). Black line 7 is the global threshold of Kanji et al. (2003). Bar chart shows the number of rainfall events that have resulted in landslides in different study areas in Italy. Equations for the thresholds are listed in Table 2.

It is worth comparing the $E D$ threshold curves defined for Calabria with similar $E D$ thresholds. Figure 11 shows the new regional threshold $\left(T_{5, \mathrm{C}}\right)$ and the sub-regional thresholds for the Tyrrhenian $\left(T_{5, \mathrm{TAR}}\right)$ and the Ionian $\left(T_{5, \mathrm{IAR}}\right)$ alert regions, for the $5 \%$ exceedance probability level, together with the $E D$ threshold curves established by Brunetti et al. (2013) for Calabria $\left(T_{\mathrm{Cal}}\right)$, and by Peruccacci et al. (2012) for the Abruzzo, Marche and Umbria $\left(T_{5, \mathrm{AMU}}\right)$ regions, central Italy. Also shown are the global $E D$ thresholds proposed by Innes (1983) and by Kanji et al. (2003). The new $T_{5, \mathrm{C}}$ threshold and the pre-existing $T_{\mathrm{Cal}}$ threshold are based on different sets of $(D, E)$ empirical data: (i) 113 events with rainfall duration $1 \leq D \leq 1080 \mathrm{~h}$ for $T_{\text {Cal }}$, and (ii) 186 events with rainfall duration $1 \leq D \leq 451 \mathrm{~h}$ for $T_{5, \mathrm{C}}$. Despite the significant increase in the number of empirical data (73, a $65 \%$ increase), the two thresholds are virtually identical. As discussed before, the sub-regional thresholds for the Tyrrhenian $\left(T_{5, \mathrm{TAR}}\right)$ and the Ionian $\left(T_{5, \mathrm{IAR}}\right)$ alert zones are different from the regional threshold $\left(T_{5, \mathrm{C}}\right)$, and particularly the $T_{5 \text {,IAR }}$ threshold. However, the data set used to prepare this threshold is small (69 data points), and the difference may be an artefact caused by the scarcity of the data. The new regional threshold for Calabria $\left(T_{5, \mathrm{C}}\right)$ is higher than the threshold obtained for the Abruzzo, Marche and Umbria regions, central Italy by Peruccacci et al. (2012). Based on this result, for the same rainfall duration the cumulated amount of event 
rainfall necessary to trigger landslides is larger in Calabria than in central Italy. The difference increases with increasing rainfall durations (Fig. 11). Finally, for all the considered rainfall durations, the $E D$ threshold for Calabria $\left(T_{5, \mathrm{C}}\right)$ is higher than the threshold proposed by Innes (1983), and significantly lower than the threshold proposed by Kanji et al. (2003).

\section{Conclusions}

We compiled a catalogue of 186 rainfall events that resulted in 251 landslides in Calabria, southern Italy, from January 1996 to September 2011. Using this information and rainfall measurements obtained from two synergic networks of rain gauges, we determined new regional cumulated event rainfall - rainfall duration $(E D)$ thresholds for possible shallow landslide occurrence in Calabria. The thresholds were determined for the $1 \%$ and the $5 \%$ exceedance probability levels adopting the procedure proposed by Brunetti et al. (2010) and changed by Peruccacci et al. (2013) to evaluate the uncertainty associated with the thresholds. The new regional $E D$ thresholds are slightly lower than expected. The result is due to an asymmetric distribution of the empirical $(D, E)$ points around their mean tendency line (Brunetti et al., 2010). The asymmetry may be a statistical artefact due to the limited number of data, or it may reflect a specific characteristic of the landslide-triggering rainfall events in Calabria.

Segmentation of the catalogue of rainfall events that triggered landslides into lithological domains, soil regions, rainfall zones, and seasonal periods resulted in a number of empirical data points in each environmental class that was insufficient to determine reliable thresholds. However, it allowed for two conclusions about the role of the environmental factors in the rainfall conditions responsible for shallow landslides in Calabria. First, the conditions for landslide occurrence in different soil regions in Calabria cannot be discriminated with the available data. Second, for short rainfall durations $(D \leq 24 \mathrm{~h})$, lower amounts of cumulated event rainfall are required to trigger landslides in the Tyrrhenian (western) alert region than in the Ionian (eastern) alert region.

We expect the new regional $E D$ rainfall thresholds defined for Calabria and the sub-regional thresholds defined for the Tyrrhenian and Ionian alert regions to be used in regional and national landslide warning systems (Brunetti et al., 2009; Rossi et al., 2012). The thresholds can also be used for landslide hazard and risk assessments, and for erosion and landscape studies in southern Italy, and in similar physiographic regions in the Mediterranean area.

Acknowledgements. The work was supported by a grant of the Italian National Department for Civil Protection (DPC). C. Vennari and S. L. Gariano were supported by DPC grants. We thank the local fire brigades for providing landslide information, and the Functional Centre of the Regional Agency for Environmental
Protection in Calabria (ARPACAL) for access to rainfall data. We acknowledge two anonymous referees for their constructive comments.

Edited by: P. Tarolli

Reviewed by: two anonymous referees

\section{References}

Aleotti, P.: A warning system for rainfall-induced shallow failures, Eng. Geol., 73, 247-265, 2004.

Amodio-Morelli, L., Bonardi, G., Colonna, V., Dietrich, D., Giunta, G., Ippolito, F., Liguori, V., Lorenzoni, S., Paglionico, A., Perrone, V., Piccarreta, G., Russo, M., Scandone, P., Zanettin Lorenzoni, E., and Zuppetta, A.: L'arco calabro-peloritano nell'orogene appenninico-maghrebide, Mem. Soc. Geol. Ital., 17, 1-60, 1976 (in Italian).

ARSSA: I suoli della Calabria, Monografia divulgativa, ed. Rubbettino, Soveria Mannelli (CZ) - Italy, 385, 2003 (in Italian).

Bellecci, C., Federico, S., Casella, G., Avolio, E., Lo Feudo, T., and Sisca, M.: Intense Precipitation in southern Italy, in: "New Trends in Hydrology", Editoriale BIOS, Cosenza, Italy, 57-74, 2002.

Boschi, E., Guidoboni, E., Ferrari, G., Mariotti, D., Valensise, G., and Gasperini, P.: Catalogue of strong Italian earthquakes, Ann. Geophys., 43, 340-868, 2000,

http://www.ann-geophys.net/43/340/2000/.

Brunetti, M. T., Peruccacci, S., Rossi, M., Guzzetti, F., Reichenbach, P., Ardizzone, F., Cardinali, M., Mondini, A., Salvati, P., Tonelli, G., Valigi, D., and Luciani, S.: A prototype system to forecast rainfall induced landslides in Italy. Proc. of the 1st Italian Workshop on Landslides, Rainfall-Induced Landslides: Mechanisms, Monitoring Techniques and Nowcasting, 2009.

Brunetti, M. T., Peruccacci, S., Rossi, M., Luciani, S., Valigi, D., and Guzzetti, F.: Rainfall thresholds for the possible occurrence of landslides in Italy, Nat. Hazards Earth Syst. Sci., 10, 447-458, doi:10.5194/nhess-10-447-2010, 2010.

Brunetti, M. T., Luino, F., Vennari, C., Peruccacci, S., Biddoccu, M., Valigi, D., Luciani, S., Cirio, C. G., Rossi, M., Nigrelli, G., Ardizzone, F., Di Palma, M., and Guzzetti, F.: Rainfall thresholds for possible occurrence of shallow landslides and debris flows in Italy, in: "Dating methods of alluvial processes on fans and cones, Advances in Global Change Research Series", edited by: Stoffel, M., Bollschweiler, M., and Luckman, B. H., 47, 327-339, doi:10.1007/978-94-007-4336-6_22, Springer Science+Business Media Dordrecht, 2013.

Caine, N.: The rainfall intensity-duration control of shallow landslides and debris flows, Geografiska Annal, 62A, 23-27, 1980.

Calcaterra, D., Parise, M., Palma, B., and Pelella, L.: The influence of meteoric events in triggering shallow landslides in pyroclastic deposits of Campania, Italy, in: Proc. 8th Int. Symp. On Landslides, edited by: Bromhead, E., Dixon, N., and Ibsen, M. L., 1, 209-214, Cardiff, 2000.

Campbell, R. H.: Soil slips, debris flows, and rainstorms in the Santa Monica Mountains and vicinity, Southern California, US Geological Survey Professional Paper, 851, 51 pp., 1975.

Ceriani, M., Lauzi, S., and Padovan, N.: Rainfall thresholds triggering debris-flows in the alpine area of Lombardia Region, central Alps - Italy, Proc. Man and Mountain, I Conv. Intern. per la 
Protezione e lo Sviluppo dell'ambiente montano, Ponte di legno (BS), 123-139, 1994.

Compagnoni, B., Cirese, E., Damiani, V., Finetti, I., Pannuti, S., Rigano, C., Sorrentino, F., and Valletta, M.: Carta Geologica d'Italia - Scala 1:500.000, in 5 fogli, Servizio Geologico d'Italia, organo cartografico di Stato, Roma, 1976-1983 (in Italian).

Corominas, J.: Landslides and climate. Keynote lecture, in: Proceedings 8th International Symposium on Landslides, edited by: Bromhead, E., Dixon, N., and Ibsen, M. L., Cardiff: A.A. Balkema, 4, 1-33, 2000.

Crosta, G. B. and Frattini, P.: Rainfall thresholds for triggering soil slips and debris flow, Proc. of the 2nd EGS Plinius Conference on Mediterranean Storms: Publication CNR GNDCI, 2547, 463 487, 2001.

Cruden, D. M. and Varnes, D. J.: Landslides Types and Processes, in: "Landslides: Investigation and Mitigation", edited by: Turner, A. K. and Schuster, R. L., Transportation Research Board Special Report 247, National Academy Press, WA, 36-75, 1996.

Efron, B.: Bootstrap methods: another look at jackknife, Ann. Stat., 7, 1-26, 1979.

Efron, B. and Tibshirani, R. J.: An Introduction to the Bootstrap, Chapman and Hall, New York, 1994.

Endo, T.: Probable distribution of the amount of rainfall causing landslides, Annual Report 1968, Hokkaido Branch, For. Exp. Stn., Sapporo, Japan, 122-136, 1969.

Gullà, G., Antronico, L., Iaquinta, P., and Terranova, O.: Susceptibility and triggering scenarios at a regional scale for shallow landslides, Geomorphology, 99, 39-58, 2008.

Guzzetti, F., Peruccacci, S., Rossi, M., and Stark, C. P.: Rainfall thresholds for the initiation of landslides in central and southern Europe, Meteorol. Atmos. Phys., 98, 239-267, 2007.

Guzzetti, F., Peruccacci, S., Rossi, M., and Stark, C. P.: The rainfall intensity-duration control of shallow landslides and debris flow: an update, Landslides, 5, 3-17, 2008.

Innes, J. L.: Debris flows, Prog. Phys. Geog., 7, 469-501, 1983.

Iovine, G., Gariano, S. L., and Terranova, O.: Alcune riflessioni sull'esposizione al rischio da frane superficiali alla luce dei recenti eventi in Italia meridionale, Geologi Calabria, 10, 4-31, 2009 (in Italian).

Kanji, M. A., Massad, F., and Cruz, P. T.: Debris flows in areas of residual soils: occurrence and characteristics, Int. Workshop on Occurrence and Mechanisms of Flows in Natural Slopes and Earthfills, Iw-Flows2003, 14-16 May 2003, Sorrento, Patron ed., Bologna, 2, 1-11, 2003.

Monachesi, G. and Stucchi, M.: NT4.1 a parametric catalogue of damaging earthquakes in the Italian area. CNR, Gruppo Nazionale Difesa dai Terremoti, Milano, available at: http:// emidius.mi.ingv.it/NT/ (last access: 11 February 2014), 1997.

Monaco, C. and Tortorici, L.: Active faulting in the Calabrian arc and eastern Sicily, J. Geodyn., 29, 407-424, 2000.

Onodera, T., Yoshinaka, R., and Kazama, H.: Slope failures caused by heavy rainfall in Japan, in: Proceedings 2nd International Congress of the Int. Ass. Eng. Geol. San Paulo, 11, 1-10, 1974.

Peruccacci, S., Brunetti, M. T., Luciani, S., Vennari, C., and Guzzetti, F.: Lithological and seasonal control of rainfall thresholds for the possible initiation of landslides in central Italy, Geomorphology, 139-140, 79-90, 2012.
Polemio, M. and Petrucci, O.: Occurrence of landslide events and the role of climate in the twentieth century in Calabria, southern Italy, Q. J. Eng. Geol. Hydrogeol., 43, 403-415, 2010.

Reichenbach, P., Cardinali, M., De Vita, P., and Guzzetti, F.: Hydrological thresholds for landslides and floods in the Tiber River Basin (central Italy), Environ. Geol., 35, 146-159, 1998.

Rossi, M., Peruccacci, S., Brunetti, M. T., Marchesini, I., Luciani, S., Ardizzone, F., Balducci, V., Bianchi, C., Cardinali, M., Fiorucci, F., Mondini, A. C., Reichenbach, P., Salvati, P., Santangelo, M., Bartolini, D., Gariano, S. L., Palladino, M., Vessia, G., Viero, A., Antronico, L., Borselli, L., Deganutti, A. M., Iovine, G., Luino, F., Parise, M., Polemio, M., and Guzzetti, F.: SANF: National warning system for rainfall-induced landslides in Italy, in: Landslides and Engineered Slopes, Protecting Society through Improved Understanding, edited by: Eberhardt, E., Froese, C., Turner, A. K., and Leroueil, S., Taylor \& Francis Group, London, ISBN 978-0-415-62123-6, 1895-1899, 2012.

Salvati, P., Bianchi, C., Rossi, M., and Guzzetti, F.: Societal landslide and flood risk in Italy, Nat. Hazards Earth Syst. Sci., 10, 465-483, doi:10.5194/nhess-10-465-2010, 2010.

Sorriso-Valvo, G. M.: The geomorphology of Calabria. A sketch, Geogr. Fis. Dinam. Quat., 16, 75-90, 1993.

Terranova, O.: Regional analysis of severe rainfall events, in: Fast slope movements. Prediction and prevention for risk mitigation, edited by: Picarelli, L., 497-501, Patron Editore, Bologna, ISBN 9788855528337, 2003.

Terranova, O.: Caratteristiche degli eventi pluviometrici a scala giornaliera in Calabria, in: XXIX Convegno di Idraulica e Costruzioni Idrauliche, Trento, 7-10 settembre, Editoriale Bios, Cosenza, Italy, 2, 343-350, ISBN 88-7740-382-9, 2004 (in Italian).

Terranova, O. G. and Iaquinta, P.: Temporal properties of rainfall events in Calabria (southern Italy), Nat. Hazards Earth Syst. Sci., 11, 751-757, doi:10.5194/nhess-11-751-2011, 2011.

Terranova, O., Iaquinta, P., Gariano, S. L., Iovine, G., Antronico, L. Vennari, C., Brunetti, M. T., Peruccacci, S., Luciani, S., Bartolini, D., Palladino, M. R., Vessia, G., Viero, A., Deganutti, A. M., Luino, F., Parise, M., and Guzzetti, F.: Rainfall events able to trigger shallow landslides in Calabria (southern Italy), Rend. On line Soc. Geol. It, 24, 310-312, 2013.

Tortorici, L., Monaco, C., Tansi, C., and Cocina, O.: Recent and active tectonics in the Calabrian Arc (southern Italy), Tectonophysics, 243, 37-55, 1995.

Trigila, A., Iadanza, C., and Spizzichino, D.: Quality assessment of the Italian Landslide Inventory using GIS processing, Landslides, 7, 455-470, 2010

Versace, P., Ferrari, E., Gabriele, S., and Rossi, F.: Valutazione delle piene in Calabria, Geodata, 30, CNR IRPI-GNDCI, Cosenza, Italia, 1989 (in Italian).

Westaway, R.: Quaternary uplift of southern Italy, J. Geophys. Res., 98, 21741-21772, 1993.

Wieczorek, G. F. and Glade, T.: Climatic factors influencing occurrence of debris flows, in "Debris flow hazards and related phenomena”, edited by: Jakob, M. and Hungr, O., Berlin Heidelberg, Springer, 325-362, 2005. 